\title{
Antioxidant Properties and Monoterpene Composition of 13 Different Pine Resin Samples from Turkey
}

\author{
Belkis TEKGULER ${ }^{1 *}$, Ilkay KOCA, Bulent KARADENIZ², Oscar ZANNOU ${ }^{1}$, Hojjat PASHAZADEH ${ }^{1}$ \\ ${ }^{1}$ Ondokuz Mayıs University, Engineering Faculty, Food Engineering Department, Samsun, Turkey \\ 2TUBITAK MAM. Food Institute PK21, Gebze/Kocaeli, Turkey \\ ORCID ID: Belkis TEKGULER: https://orcid.org/0000-0001-7850-8013; Ilkay KOCA: https://orcid.org/0000-0001-6089-8586; Bulent \\ KARADENIZ: https:// orcid.org/0000-0003-2392-6589; Oscar ZANNOU: https:// orcid.org/0000-0003-1227-1265; Hojjat PASHAZADEH: \\ https:// orcid.org/0000-0001-8932-8165
}

\begin{abstract}
Received: 12.11 .2021
Accepted: 29.12 .2021

Published online: 30.12 .2021

Issue published: 31.12 .2021

Abstract: Pine resin has been used as a traditional health-promoting medicinal food in Turkey and some countries for centuries. In the present study, the antioxidant potential and the monoterpene profile of 13 pine resin samples purchased from herbalists in different provinces of Turkey were investigated. According to the analysis results, there were differences between the pine resin samples, especially in terms of color and antioxidant properties. The experimental results demonstrated that the pine resin had strong in-vitro antioxidant effects. Total phenolic, FRAP, and DPPH (EC50) values ranged between 23.19 and 379.44 mgGAE g-1 68.85 and $758.80 \mu \mathrm{mol} \mathrm{Fe}^{2+} \mathrm{g}^{-1}, 54.36$ and $1006.97 \mu \mathrm{g} \mathrm{g}^{-1}$, respectively. Total phenolic content values correlated well with the FRAP values. In contrast, it was found that there was a negative correlation between FRAP values and EC 50 values $\left(\mathrm{r}=-0.719^{* *}\right)$ and between total phenolic substance and $\mathrm{EC}_{50}$ values $\left(\mathrm{r}=-0.688^{* *}\right)$. Also, the monoterpene compounds of the resin were determined by applying solid-phase microextraction (SPME) and gas chromatography-mass spectroscopy. Eight monoterpene compounds were identified in different pine resin samples, including a-pinene, camphene, $\beta$-pinene, 3-carene, $\beta$-myrcene, cymene, D-limonene, and $p$-cymene. Generally, the main monoterpenes were $a$-pinene and $\beta$-pinene.
\end{abstract}

Keywords: Terpenes, total phenolic matter, volatile compounds, bioactive compounds, pinen.

\section{Türkiye'den 13 Farklı Çam Reçine Örneğinin Antioksidan Özellikleri ve Monoterpen Bileşimi}

\begin{abstract}
Öz: Çam reçinesi, yüzyıllardır Türkiye'de ve bazı ülkelerde geleneksel, sağlığı geliştirici tıbbi gıda olarak kullanılmaktadır. Bu çalışmada, Türkiye'nin farklı illerindeki aktarlardan satın alınan 13 adet çam reçinesi örneğinin antioksidan özellikleri ve monoterpen profili araştırılmıştır. Analiz sonuçlarına göre çam reçinesi örnekleri arasında özellikle renk ve antioksidan özellikler açısından farklılıklar tespit edilmiştir. Deneysel sonuçlar, çam reçinesinin güçlü in vitro antioksidan etkilere sahip olduğunu göstermiştir. Toplam fenolik, FRAP ve DPPH (EC50) değerleri sırasıyla 23.19 ve 379.44 mgGAE g-1 68.85 ve 758.80 $\mu \mathrm{mol} \mathrm{Fe}{ }^{2+} \mathrm{g}^{-1}, 54.36$ ve $1006.97 \mu \mathrm{g} \mathrm{g}^{-1}$ arasında değişmiştir. Toplam fenolik içerik değerleri, FRAP değerleri ile iyi bir korelasyon göstermiştir. Buna karşılık, FRAP değerleri ile $\mathrm{EC}_{50}$ değerleri $\left(\mathrm{r}=-0.719^{* *}\right)$ arasında ve toplam fenolik madde ile $\mathrm{EC}_{50}$ değerleri $\left(\mathrm{r}=-0.688^{* *}\right)$ arasında negatif korelasyon olduğu tespit edilmiştir. Ayrıca reçinenin monoterpen bileşikleri, katı faz mikroekstraksiyon (SPME) ve gaz kromatografisi-kütle spektroskopisi uygulanarak belirlenmiştir. Farklı çam reçinesi numunelerinde $a$-pinen, camphene, $\beta$-pinene, 3-carene, $\beta$-myrcene, cymene, $\mathrm{D}$-limonen ve $\mathrm{p}$-cymene olmak üzere sekiz monoterpen bileşiği tanımlanmıştır. Genel olarak, örneklerdeki başlıca monoterpenler $a$-pinen ve $\beta$-pinendir.
\end{abstract}

Anahtar kelimeler: Terpenler, toplam fenolik madde, uçucu bileşikler, biyoaktif bileşikler, pinen.

\section{Introduction}

Plants and herbal products are used in many areas of human life, including as a source of food and as medicine, fuel, and clothing (Tetik et al., 2013). It is known that many plants have been used for medicinal purposes since ancient times. The oldest information about the medicinal use of plants is found in Chinese, Egyptian, and Greek historical sources. Some drugs were produced and exported in Anatolia during the Hittites civilization (Sar1 et al., 2008). Herbal medicines, widely used in ancient civilizations, are still used today. Exact figures on how much of the world's population uses local and traditional medicines are unknown. However, according to WHO, herbal products' global market value size is 62 billion USD that is expected to reach 5 trillion USD by 2050 (Hayta et al., 2014). Nowadays, it is reported that the number of plants used in the world is around 20000. 4000 of them are widely used for medicinal purposes and about 400 of them are traded (Sar1 et al., 2008).

Turkey has a rich flora due to its variable climate and many ecological regions. This diversity in vegetation provides a rich source of medicinal plants used by the Anatolian civilization (Hayta et al., 2014). Pinus spp., which naturally grows in our country, belongs to Pinaceae, the most prominent family of conifers. The genus Pinus includes about 100 species, used from its leaves to its bark and seeds in many countries in the Northern hemisphere. (Mármol et al., 2019; Dziedziński et al., 2021). The resin produced from pine (Pinus spp.) has been widely used in adhesives, soaps, insecticide, construction materials, artworks, and even in embalming fluid throughout history (Alkan et al., 2016; Neis et al., 2019). It has been observed that natural resins obtained from trees and herbaceous plants used in archaeological materials cannot be 
destroyed by fungi, insects, and microorganisms (Alkan et al., 2016). There are various pine-based food additives and food products marketed in Korea. Some of them are beverages, wine, tea, and candy (Yu et al., 2004). Pine resin is used to treat skin diseases, burns and scald wounds, tracheitis, pulmonary tuberculosis and is an excellent antiseptic. In Turkey, the resin is boiled and used externally in abscesses or chewing gum to clean teeth and to prevent bad breath. The resin is dissolved in hot water and applied externally to wounds and cuts (Ulukanlı et al., 2014).

Resin is secreted to survive against abiotic effects in plants. It contains many bioactive chemicals, including main terpenoids. Thanks to these bioactive compounds, the resin has protective effects against external factors such as pathogenic microorganisms and insects (Neis et al., 2019). The resin biosynthesized by epithelial cells is found in channels called schizogenous or in special vesicles in the cells of trees (Alkan et al., 2016).

Monoterpene hydrocarbons, oxygenated monoterpenes, sesquiterpenes, oxygenated sesquiterpenes, and carbonyl compounds can be mentioned as volatile compounds of Pinus (Yu et al., 2004). It is known that the composition and amounts of many compounds in plants vary according to the parts of the plant (leaf, stem, branch, root, and similar parts), where it grows, according to the season and location. Tiberi et al. (1999) listed the monoterpenes in the extracts of $P$. pinea needles as a-pinene, $\beta$-pinene, $\delta 3$-carene, myrcene, limonene, and phellandrene.

To the best of our knowledge, in Turkey, few studies have been carried out on the resin, popularly called pine resin, rich in secondary metabolites and used in many fields from medicine to food. This study investigated the antioxidant properties and monoterpene compounds of pine resin. For this purpose, pine resin samples were obtained from herbalists in different provinces of Turkey. Two antioxidant activity methods, FRAP (Ferric reducing antioxidant power) and DPPH (diphenyl-1picrylhydrazyl) radical scavenging activity, were used. Folin's method was used to determine the total phenolic contents in the samples. It was carried out by spectrophotometric measurement of the blue color formed by phenolic compounds in alkaline medium with Folin reagent. Furthermore, the monoterpene compositions of the samples were determined by applying solid-phase microextraction (SPME) and gas chromatography-mass spectroscopy.

\section{Material and Methods}

In the present study, the thirteen pine resin samples investigated were purchased from herbalists in different provinces of Turkey (Table 1). The samples were analyzed in the Food Engineering Department Laboratory of Ondokuz Mayis University. The color measurement was performed before crushing them into powder with a glass mortar.

Table 1. Color, dry matter, and antioxidant properties of pine resin samples

\begin{tabular}{|c|c|c|c|c|c|c|c|c|}
\hline Samples & City & $L^{*}$ & $a^{*}$ & $b^{*}$ & Moisture \% & Total phenolics mgGAE g-1 & FRAP $\mu \mathrm{mol} \mathrm{g}^{-1}$ & $\mathrm{EC}_{50}, \mu \mathrm{g} \mathrm{g}^{-1}$ \\
\hline 1 & Mersin & 75.60 & -0.52 & 19.47 & 3.53 & 29.82 & 78.76 & 618.00 \\
\hline 2 & Bolu & 35.87 & 4.42 & 9.16 & 4.80 & 42.01 & 183.07 & 154.55 \\
\hline 3 & Bolu & 73.15 & -0.37 & 13.01 & 3.79 & 36.07 & 75.05 & 401.15 \\
\hline 4 & Bolu & 60.94 & 1.42 & 15.36 & 2.61 & 378.77 & 712.87 & 54.36 \\
\hline 5 & Bolu & 47.17 & 7.15 & 14.06 & 3.50 & 73.16 & 442.36 & 152.45 \\
\hline 6 & Bolu & 70.95 & 2.27 & 22.72 & 3.39 & 23.19 & 68.85 & 451.03 \\
\hline 7 & Giresun & 69.40 & 2.70 & 14.78 & 3.90 & 341.94 & 758.80 & 96.31 \\
\hline 8 & Artvin & 53.47 & 5.20 & 7.43 & 3.42 & 379.44 & 752.60 & 92.06 \\
\hline 9 & Samsun & 61.44 & 1.42 & 16.31 & 3.78 & 25.82 & 147.22 & 681.99 \\
\hline 10 & Aydın & 75.74 & -0.02 & 18.48 & 4.23 & 24.94 & 146.47 & 1006.97 \\
\hline 11 & İzmir & 68.43 & 1.06 & 19.81 & 3.32 & 27.69 & 73.81 & 496.07 \\
\hline 12 & İstanbul & 73.88 & -0.31 & 17.29 & 3.51 & 32.26 & 141.85 & 572.40 \\
\hline \multirow[t]{3}{*}{13} & Edirne & 70.62 & 1.30 & 19.97 & 3.47 & 26.44 & 83.96 & 459.24 \\
\hline & Mean & 64.36 & 1.98 & 15.99 & 3.65 & 110.89 & 281.97 & 402.81 \\
\hline & Std dev & 12.23 & 2.35 & 4.38 & 0.51 & 146.67 & 279.62 & 284.09 \\
\hline
\end{tabular}

Where $L^{*}$ is luminescens $\left(L^{*}=0\right.$, black; $L^{*}=100$, white); $a^{*}$ is redness and greenness $\left(+60\right.$, red; -60 , green) and the $b^{*}$ value represents yellowness and blueness ( +60 , yellow; -60 , blue).

${ }^{* *} \mathrm{EC}_{50}$ value of positive control (trolox) was $66.54 \mu \mathrm{g} \mathrm{mL}-1$

\subsection{Color analysis}

The color of the samples was measured by Minolta CR 400 (Japan) color measuring device. The color was expressed as $L^{*}\left(100\right.$, lightness; 0, darkness), $a^{*}$ (+, redness; -, greeness), $b^{*}(+$, yellowness; -, blue). White ceramic (No:19633162) was used in the standardization of the device.

\subsection{Moisture content}

The moisture of the samples was determined by drying in an oven with vacuum at $70^{\circ} \mathrm{C}$ to constant weight (AOAC, 2000).

\subsection{Extraction procedure}

One gram of the powder sample was mixed with $25 \mathrm{~mL}$ of $80 \%$ methanol and the mixture was left to dissolve for $12 \mathrm{~h}$ 
at room temperature and then filtered by 0.45 micron disposable filter.

\subsection{Total phenolic analysis}

According to Singleton and Rossi (1965), the total phenolics of the extracts were determined. $50 \mu \mathrm{L}$ of the filtrate was mixed with $50 \mu \mathrm{L}$ of Folin-Ciocalteau reagent and $250 \mu \mathrm{L}$ of $10 \%$ sodium carbonate and placed in the dark for two h; its absorbance was read at $760 \mathrm{~nm}$ in a spectrophotometer. The calibration curve was drawn using gallic acid (Sigma) as a standard and the total phenolic content was expressed as mgGAE g-1.

\subsection{Antioxidant activity}

\section{Ferric reducing antioxidant power (FRAP)}

According to Gao et al. (2000), the FRAP assay was determined with some modifications. FRAP reagent consists of $10 \mathrm{mM}$ TPTZ (tripyridyltriazine) in $40 \mathrm{mM} \mathrm{HCl}$, $20 \mathrm{mM}$ ferric chloride and $300 \mathrm{mM}$ acetate buffer $(\mathrm{pH}$ $3.6)$ in the ratio of 1:1:10 (v/v/v). FRAP solution $(50 \mu \mathrm{L})$ was mixed with methanolic extract $(950 \mu \mathrm{L})$ for this analysis. After $5 \mathrm{~min}$, the absorbance of the colored mixture was measured at $593 \mathrm{~nm}$. FRAP was calculated from a calibration curve using $\mathrm{FeSO}_{4}$ as the standard and expressed as $\mu \mathrm{mol} \mathrm{FeSO}_{4}$ equivalents per $\mathrm{g}\left(\mu \mathrm{mol} \mathrm{Fe}{ }^{2+} \mathrm{g}^{-1}\right)$.

\section{Radical scavenging effect test}

DPPH (1,1-diphenyl-2-picrylhydrazyl) is a free radical with unpaired electrons. The radical scavenging effect of the resin was estimated by published methods (Nakajima et al., 2004; Thaipong et al., 2006). $50 \mu \mathrm{L}$ of different concentrations of resin extracts were mixed with $1000 \mu \mathrm{L}$ of $100 \mu \mathrm{M}$ DPPH and incubated at room temperature for $120 \mathrm{~min}$ and absorbance was read spectrophotometrically at $515 \mathrm{~nm}$. Trolox (a water-soluble vitamin E analog) was used as a positive control. The inhibition of free radicals from $\mathrm{DPPH}$ as a percentage was calculated with the following equation:

DPPH radical scavenging activity $(\%)=\left[\left(\mathrm{A}_{0}-\mathrm{A}_{1}\right) / \mathrm{A}_{0}\right] \times 100$

Where; $\mathrm{A}_{0}$ is the absorbance of the control reaction, $A_{1}$ is the absorbance of the extracts. The $E_{50}$ value was defined as the concentration of $50 \%$ of DPPH radical scavenging activity.

\subsection{Monoterpene profiles determination}

The sample $(1 \mathrm{~g})$ and $22 \mathrm{~mL}$ of water were placed in the headspace vial (Perkin Elmer, USA). The headspace vial was tightly sealed with a silicone/polytetrafluoroethylene (PTFE) septum (Perkin Elmer, USA) and aluminum cover (Perkin Elmer, USA). The sample was heated at $80^{\circ} \mathrm{C}$ for one hour and then put into headspace autosampler. The transfer line was a fused silica $1 \mathrm{~m} \times 320$ $\mu \mathrm{m}$. The vial pressure was fixed at $10 \mathrm{psi}$ and column pressure was kept at 25 psi. The needle temperature was set at $90^{\circ} \mathrm{C}$ and transfer line temperatures at $100^{\circ} \mathrm{C}$. The trap hold time was $6 \mathrm{~min}$ and the outlet split was on. Desorbed compounds were automatically injected into a GC column (Optima-Wax, $60 \mathrm{~m}$ length, $0.25 \mathrm{~mm}$ inner diameter, $0.25 \mu \mathrm{m}$ film thickness). The oven temperature was $70^{\circ} \mathrm{C}$. The flow rate of the helium carrier gas was $1 \mathrm{~mL}$ $\mathrm{min}^{-1}$. The injection was performed in the splitless mode $\left(200^{\circ} \mathrm{C}\right.$ injection port temperature). The GC column temperature was programmed as follows: 1 . holding for 5 min at $35^{\circ} \mathrm{C}$, 2. increasing from $35^{\circ} \mathrm{C}$ to $160^{\circ} \mathrm{C}$ at a rate of $3^{\circ} \mathrm{C} \min ^{-1}$, and 3 . holding at $160^{\circ} \mathrm{C}$ for $15 \mathrm{~min}$. The MS conditions were: $200^{\circ} \mathrm{C}$ for ion source temperature; $70 \mathrm{eV}$ for ionization energy; 33-300 amu for mass scan range; 350 $\mathrm{V}$ electron multiplier voltage; $0.25 \mathrm{~s}$ for scan time, 0.05 for standby time; and electron ionization (EI) as ion mode. The analyses were performed in triplicate.

The monoterpene composition was determined by comparing their retention index and mass spectra with a commercial spectra database (Wiley 6, NBS 75k) and the instrument's internal library. $10 \mu \mathrm{L}$ methyl alcohol: water (1:1) mixture was used as internal standard. The standard peaks were compared to those of samples based on their retention time and mass spectra. The unknown chromatograms were identified using Mass Spectral Libraries according to the retention index calculated thanks to the n-alkane series (C6-C20) (Alasalvar et al., 2012).

\subsection{Statistical analysis}

The data were evaluated as mean value \pm standard deviation. The data was also subjected to a correlation analysis using Pearson's correlation coefficient.

\section{Results and Discussion}

The results showing the color characteristics, moisture contents, and antioxidant properties of the examined 13 different pine resin samples were given in Table 1.

$L^{*}$ values of the samples varied between 35.87 and $75.74, a^{*}$ values between -0.52 and $+7.15, b^{*}$ values between +7.43 and +22.72 . There are huge differences between the color values of the samples. It was determined that the color of 3 samples $(2,5$, and 8 numbers) was dark, except for 4 samples $(1,3,10$, and 12 numbers), the redness values of the other samples were higher. Generally, the yellowness values were high in all samples. This difference in colors is probably due to different places where the trees grow as well as different drying conditions and harvesting times. Moisture contents of pine resin varied between 2.61 and $4.80 \%$. It was observed that some samples (2 and 10 numbers) had higher moisture content than the other samples. These values were closely related to the conditions of drying the pine resin.

In the human body, reactive oxygen species such as free radicals, superoxides, hydroxyl radicals, and hydrogen peroxide are produced during the endogenic metabolic processes. The reactive matters readily react with DNA, lipids, and proteins resulting in cell damage. However, the antioxidants give hydrogen atoms to free radicals. Thus, the antioxidants prevent the cell from harmful effects of the radicals. Today, interest in natural antioxidants has increased due to their positive effects on health. This interest has led to a focus on research on the antioxidants in various disciplines. Pine products are rich in antioxidants. To date, different parts of the trees (bark, needles, shoots, seeds), various extraction methods, and solvents have been used in the studies investigating the antioxidant properties of Pinus trees (Dziedziński et al., 2021).

Phenolic compounds, including flavonoids, have biological effects. The source of antioxidant activity is polyphenolic compounds. The radical scavenging 
activities and inhibition of lipid peroxidation are measured to determine the antioxidant activity resulting from the polyphenolic contents of the plant material. The total phenolic content can be determined by measuring the color intensity of the phenolic compound extract with the Folin-Ciocalteau reagent. As a result of many studies, it has been observed that the best solvent for the extraction of phenolics is the methanol: water mixture (Kwak et al., 2006). In this study, total phenolic substances were investigated with the Folin technique and it was found

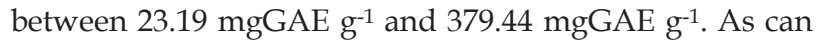
be seen in Table 1 , there were significant variations among the samples compared with each other. Such a considerable variation is presumably due to the location and climatic conditions where it grows. Compared with other researchers, Kwak et al. (2006) found total phenolic contents as $57.71 \mathrm{mg} \mathrm{g}^{-1}$ dry weight basis in pine needles of Pinus densiflora extracted by $75 \%$ ethanol. This value was within the limits of our findings.

FRAP values of pine resin ranged from 68.85 to $758.80 \mu \mathrm{mol} \mathrm{Fe}{ }^{2+} \mathrm{g}-1$. The FRAP values of 3 samples $(4,7$, and 8 numbers) are much higher than the others as seen in Table 1. Antioxidant activities of the samples were analyzed by a DPPH free radical assay using spectrophotometric. $\mathrm{EC}_{50}$ value indicates the concentration of sample that could inhibit 50 percent reduction of DPPH radical (Table 1). The $\mathrm{EC}_{50}$ value of the samples ranged from 54.36 to $1006.97 \mu \mathrm{g} \mathrm{g}^{-1}$. Generally, the antioxidant power of the samples in our study was lower than the antioxidant power of Trolox (EC 50 value $66.54 \mu \mathrm{g} \mathrm{mL}^{-1}$ ) used as a positive control. The lower the $\mathrm{EC}_{50}$ value, the higher the antioxidant activity. The samples used had less potential antioxidant activity than positive control "Trolox".

Park et al. (2011) extracted Pinus densiflora needles in hot water, ethanol, hexane, hot water-hexane, and hot water-ethanol. They analyzed the proanthocyanidin contents and antioxidant activities of the sample extracts. At the end of this research, they found that the hot water extract $\left(\mathrm{EC}_{50}\right.$ value $\left.=0.27 \mathrm{mg} \mathrm{mL}^{-1}\right)$ had superior antioxidant activity than the other extracts.

Tillah et al. (2017) determined the antibacterial and antioxidant activities of Pinus merkusii, P. oocarpa, P. insularis, Agathis loranthifolia resins. They found that $P$. oocarpa resin extracted in n-hexane had the most antibacterial potential compared with the other samples. For the antioxidant activity, they expressed that $P$. merkusii resin extracted in $n$-hexane had the lowest $\mathrm{EC}_{50}$ value (60.203 $\mathrm{mg} \mathrm{mL}^{-1}$ ) compared with the other extracts and the $\mathrm{EC}_{50}$ value changed in relation to the solvent.

Kwak et al. (2006) determined that the $\mathrm{EC}_{50}$ value was $95.12 \mathrm{mg} \mathrm{mL}^{-1}$ in the extracts with ethyl alcohol 75\%. They concluded that pine needles would have potent antioxidative activity due to the high phenolic compounds.

Dziedziński et al. (2021) reported that the total phenolics of alcoholic extract for Pinus brutia tree barks

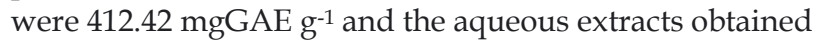
from the shoots of $P$. sylvestris was $0.86 \mathrm{mgGAE} \mathrm{g}^{-1}$ dry weight basis. It was expressed that the alcoholic extracts have higher total phenolic values than the aqueous extracts. They declared that the value of $\mathrm{EC}_{50}$, which expresses free radical tests, for $P$. koraiensis seeds extracts in $40 \%$ aqueous ethanol and P. brutai bark extracts in $80 \%$ aqueous methanol were $0.023 \mathrm{mg} \mathrm{mL}^{-1}$ and $9.17 \mu \mathrm{g} \mathrm{mL}-1$, respectively. Many previous studies clearly stated that the antioxidant activity of the plant products was affected by whether extraction solvents contain water. The use of aqueous mixtures of water and organic solvents, such as ethanol, methanol, acetone, isopropanol, or acetonitrile, remarkably increases the antioxidant efficacy of the extracts (Dziedziński et al., 2021).

Vankatesan et al. (2019) investigated the antioxidant activity of Pinus densiflora needle extracts in water:ethanol mixture ratios of $0,20,40,60,80$, and 100 percent. They determined that the highest radical scavenging capacity for the extract contained $40 \%$ of ethanol. It was followed by the values of the extracts containing $60 \%, 20 \%, 80 \%, 0 \%$, and $100 \%$ ethanol, respectively.

According to our findings, FRAP values the extracts correlated well with the total phenolic content $\left(\mathrm{r}=0.958^{* *}\right)$, while a high negative correlation was found between FRAP values and $\mathrm{EC}_{50}$ values $\left(\mathrm{r}=-0.719^{* *}\right)$. However, the correlation between total phenolic substance and $\mathrm{EC}_{50}$ values was not as high as in FRAP values $\left(\mathrm{r}=-0.688^{* *}\right)$. Xie et al. (2015) reported that these differences could be attributed to the different stoichiometry of the DPPH and FRAP assay reactions. In addition, the phenolic composition differences in extracts, which solvent used, and their different solubility in the test systems may also affect their antioxidant activity.

The monoterpene compositions of the samples were determined by applying solid-phase microextraction (SPME) and gas chromatography-mass spectroscopy and the results were shown in Table 2. The monoterpene composition (\%) was determined by comparing of their retention index and retention time (Fig. 1).

Eight monoterpene compounds were identified in the different samples of the resin, including a-pinene, camphene, $\beta$-pinene, 3 -carene, $\beta$-myrcene, cymene, $\mathrm{D}$ limonene, and $p$-cymene. Most of these volatile compounds have been reported previously in various species of Pinus (Ustun et al., 2012; Kadri et al., 2015; Xie et al., 2015; Kurti et al., 2019; Sharma et al., 2020).

In contrast, cymene was identified in Pinus samples for the first time in the present study. The compounds $a$ pinene, $\beta$-pinene, and 3 -carene were the most dominant monoterpene compounds determined in the studied samples. a-pinene was found as the most abundant monoterpene compound in Pinus samples accounting for $21.17-51.37 \%$. a-pinene was followed by $\beta$-pinene of $0.96-$ $40.36 \%$. These results were found to be in agreement with many previous studies, which reported $a$-pinene and $\beta$ pinene as the significant volatile substances in Pinus species with concentrations ranging from 8.16 to $50.40 \%$ and from 0.35 to $47.50 \%$, respectively (Ustun et al., 2012; Xie et al., 2015; Kurti et al., 2019; Sharma et al., 2020). apinene and $\beta$-pinene exhibit diverse biological activities such as antifungal, antiviral, and antimicrobial and are generally recognized as safe (GRAS) (Dziedziński et al., 2021).

As shown in Table 2, the percent monoterpene composition of the pine resin samples varied significantly 
according to the herbalist from which it was purchased. The highest amount of $a$-pinene was found in the samples numbered as $4(51.37 \%), 10(48.54 \%), 3(47.05 \%), 5$ (46.27\%), 2 (44.08\%), 11 (41.37\%), 13 (41.28\%), 6 (41.07\%), 1 $(38.01 \%), 8(37.33 \%)$, and $12(32.55 \%)$. The highest amount of $\beta$-pinene was determined in samples $8(40.36 \%)$ and 4 $(30.09 \%)$, while the most significant amount of 3-carene was found in sample 7 (39.27\%). Tiberi et al. (1999) listed the monoterpenes in the extracts of P.pinea needles as $a$ pinene, $\beta$-pinene, $\delta 3$-carene, myrcene, limonene, and phellandrene. Also, the correlation between monoterpene composition and antioxidant activity was examined, and generally, no statistically significant relationship was found in the present study.

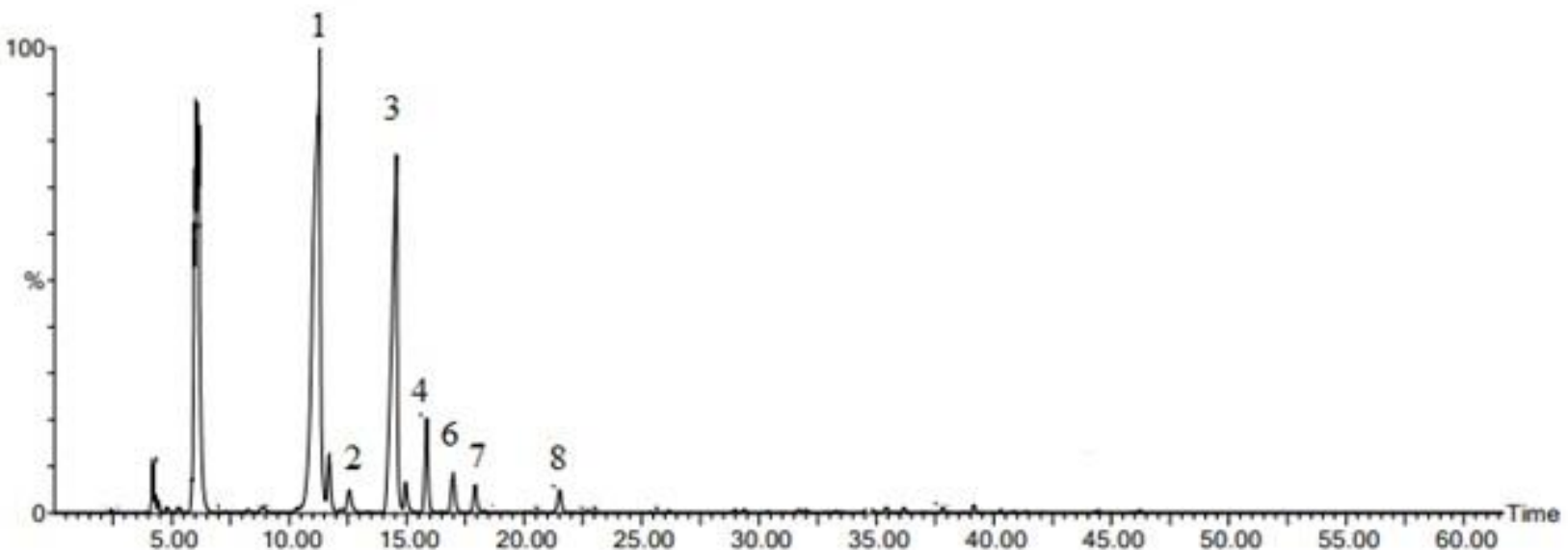

Figure 1. Typical GC-MS chromatogram of pine resin (1: a-pinene, 2: camphene, 3: $\beta$-pinene, 4: 3-carene, 6:cymene, 7: D-limonene, 8: pcymene) (5: $\beta$-myrcene is not clear for only this chromatogram but RT for $\beta$-myrcene is $16.44 \mathrm{~min}$.)

Table 2. Monoterpene profiles of the resin samples (\%)

\begin{tabular}{|c|c|c|c|c|c|c|c|c|c|}
\hline & & a-pinene & camphene & $\beta$-pinene & 3-carene & $\beta$-myrcene & cymene & D-limonene & p-cymene \\
\hline & $\mathrm{RT}, \min$ & 11.13 & 12.15 & 14.56 & 15.85 & 16.44 & 16.99 & 17.92 & 21.52 \\
\hline & RI & 1100 & 1124 & 1182 & 1214 & 1240 & 1252 & 1269 & 1355 \\
\hline \multirow{15}{*}{ 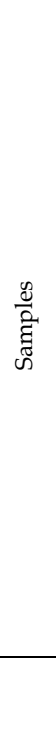 } & 1 & 38.01 & 0.1 & 21.53 & 3.66 & 0.05 & 1.8 & 1.2 & 1.08 \\
\hline & 2 & 44.08 & 0 & 6.82 & 0.64 & 0.77 & 0.27 & 0.69 & 1.15 \\
\hline & 3 & 47.05 & 0.08 & 1.58 & 0.45 & 0.54 & 0.52 & 0.12 & 0.56 \\
\hline & 4 & 51.37 & 0.02 & 30.09 & 0.92 & 0.11 & 0.03 & 0.85 & 0.44 \\
\hline & 5 & 46.27 & 0.07 & 0.96 & 0.44 & 0.96 & 0.01 & 1.12 & 0.2 \\
\hline & 6 & 41.07 & 0.54 & 13.2 & 4.95 & 0.03 & 1.29 & 1.53 & 1.47 \\
\hline & 7 & 21.17 & 0.34 & 8.67 & 39.27 & 0.84 & 1.72 & 1.79 & 0.97 \\
\hline & 8 & 37.33 & 0.96 & 40.36 & 1.3 & 1.42 & 0.12 & 2.49 & 0.11 \\
\hline & 9 & 26.65 & 0.22 & 5.07 & 3.54 & 0.08 & 1.49 & 2.01 & 2.99 \\
\hline & 10 & 48.54 & 0.69 & 26.19 & 0.77 & 0.11 & 0.77 & 1.34 & 0.26 \\
\hline & 11 & 41.37 & 2.25 & 12.05 & 4.13 & 0.04 & 1.52 & 1.49 & 1.56 \\
\hline & 12 & 32.55 & 0.76 & 18.17 & 5.51 & 0.09 & 3.29 & 1.04 & 1.75 \\
\hline & 13 & 41.28 & 1.14 & 14.69 & 6.94 & 0.1 & 1.68 & 0.77 & 0.1 \\
\hline & mean & 39.75 & 0.55 & 15.34 & 5.58 & 0.40 & 1.12 & 1.27 & 0.97 \\
\hline & std & 8.71 & 0.64 & 11.70 & 10.36 & 0.46 & 0.95 & 0.62 & 0.84 \\
\hline
\end{tabular}

${ }^{*} \mathrm{RT}$; retention time, RI; retention index

The investigated pine resin samples were obtained in line with the statements of herbalists in different cities. Therefore, the information about the process of resin before it reaches the herbalist is not clear. We can clearly state that the difference between the analysis results of the present study is that the samples were taken from different cities. However, this difference may be caused by many factors such as pine species, altitude level, seasonal conditions where the resin is collected, drying conditions of the resin, characteristics of the soil where the pine trees grow, and duration of sunshine. The current study was carried out on a limited number of materials. For this reason, the bioactive potential of pine resin could be revealed more clearly by conducting studies under controlled conditions according to these factors that can directly affect the bioactive substance and its properties.

\section{Conclusion}

In the present study, the antioxidant potential and the monoterpene profile of 13 pine resin samples purchased from different provinces of Turkey were investigated. FRAP, which shows antioxidant potential, positively 
correlated with total phenolic content while DPPH $\left(\mathrm{EC}_{50}\right)$ negatively correlated with total phenolic content. Both conditions (negative or positive correlation) revealed that the antioxidant activity of the samples was well correlated with the total phenolic content; thus, all the resin samples exhibited good antioxidant potential. Pine resin samples exhibited significant color values and antioxidant properties in the present study. It is known that the composition and amounts of many compounds in plants vary according to the parts of the plant (leaf, stem, branch, root, and similar parts), where it grows, and according to the season and location. The use of volatile compounds obtained from pine needles in the food industry is mentioned in the literature. However, information is needed about their usage in this industry. The antioxidant potential of pine resin, which is mainly mentioned for its use in folk medicine, and the antimicrobial properties of terpenoids allow it to be used as a food additive in today's food industry. Its use as antioxidant, antimicrobial, and flavoring in food should be investigated.

Ethics committee approval: Ethics committee approval is not required for this study.

Conflict of interest: The authors declare that there is no conflict of interest.

\section{References}

Alasalvar, C., Topal, B., Serpen, A., Bahar, B., Pelvan, E., \& Gökmen, V. (2012). Flavor characteristics of seven grades of black tea produced in Turkey. Journal of Agricultural and Food Chemistry, 60(25), 6323-6332. https://doi.org/10.1021/if301498p

Alkan, M., Alkan, H., \& Önel, A. (2016). Çam, vişne ve kayısı reçinelerinin antibakteriyal özelliklerinin incelenmesi. Caucasian Journal of Science, $3(1), 52-57$

AOAC, (2000). Official Methods of Analysis of the Association of Official Analysis Chemists (17th ed). AOAC International, Gaithersburg, MD.

Dziedziński, M., Kobus-Cisowska, J., \& Stachowiak, B. (2021). Pinus species as prospective reserves of bioactive compounds with potential use in functional food plants current state of knowledge. Plants, 10(7), 1306. https://doi.org/10.3390/plants10071306

Gao, X., Björk, L., Trajkovski, V., \& Uggla, M. (2000). Evaluation of antioxidant activies of rosehip ethanol extracts in different test systems. Journal of the Science of Food and Agriculture, 80, 2021-2027. https://doi.org/10.1002/1097-0010(200011)80:14<2021::AIDJSFA745 $>3.0 . \mathrm{CO} ; 2-2$

Hayta, S., Polat, R., \& Selvi, S. (2014). Traditional uses of medicinal plants in Elazı ̆ (Turkey). Journal of Ethnopharmacology, 154(3), 613-623. https://doi.org/10.1016/i.jep.2014.04.026

Kadri, N., Khettal, B., Aid, Y., Kherfellah, S., Montero, V.B., \& Sobhi, W. (2015). Some physicochemical characteristics of pinus (Pinus halepensis Mill., Pinus pinea L., Pinus pinaster and Pinus canariensis) seeds from North Algeria, their lipid profiles and volatile contents. Food Chemistry, 188, 184-192. https://doi.org/10.1016/j.foodchem.2015.04.138

Kurti, F., Giorgi, A., Beretta, G., Mustafa, B., Gelmini, F., Testa, C., .....\& Hajdari, A. (2019). Chemical composition, antioxidant and antimicrobial activities of essential oils of different Pinus species from Kosovo, Journal of Essential Oil Research, 31(4), 263-275. https://doi.org/10.1080/10412905.2019.1584591

Kwak, C.S., Moon, S.C. \& Lee, S.M. (2006). Antioxidant, antimutagenic, and antitumor effects of pine needles (Pinus densiflora). Nutrition and Cancer, 56(2), 162-171. https://doi.org/10.1207/s15327914nc5602_7

Mármol, I., Quero, J., Jiménez-Moreno, N., Rodríguez-Yoldi, M.J., \& AncínAzpilicueta, C. (2019). A systematic review of the potential uses of pine bark in food industry and health care. Trends in Food Science $\mathcal{E}$ Technology, 88, 558-566. https://doi.org/10.1016/j.tifs.2018.07.007

Nakajima, J.I., Tanaka, I., Seo, S., Yamazaki, M., \& Saito, K. (2004). LC/PDA/ESI-MS profiling and radical scavenging activity of anthocyanins in various berries. Journal of Biomedicine and Biotechnology, 5, 241-247. https://doi.org/10.1155/S1110724304404045

Neis, A., de Costa, F., de Araújo, A.T., Fett, J.P., \& Fett-Neto, A.G. (2019). Multiple industrial uses of non-wood pine products Franciele. Industrial
Crops
and
Products,
130,
248-258.

https://doi.org/10.1016/j.indcrop.2018.12.088

Park, Y.S., Jeon, M.H., Hwang, H.J. Park, M.R., Lee, S.H., Kim, S.G., \& Kim, M. (2011). Antioxidant activity and analysis of proanthocyanidins from pine (Pinus densiflora) needles. Nutrition Research and Practice, 5(4), 281287. https:// doi.org/10.4162/nrp.2011.5.4.281

Sarı, A.O., Oğuz, B., Bilgiç, A., Tort, N., Güvensen, A., \& Şenol, S.G. (2008). Batı Anadolu'da halk ilacı olarak kullanılan asteraceae türleri. Anadolu, 18(1), 1-15.

Sharma, A., Sharma, L., \& Goyal, R. (2020). GC/MS characterization, invitro antioxidant, anti-inflammatory and antimicrobial activity of essential oils from pinus plant species from himachal pradesh, India. Journal of Essential Oil Bearing Plants, 23(3), 522-531. https://doi.org/10.1080/0972060X.2020.1803147

Singleton, V.L., \& Rossi, J.A. (1965). Colorimety of total phenolics with phosphomolybdic-phosphotungstic acid reagents. American Journal of Enology and Viticulture, 16, 144-58.

Tetik, F., Civelek, S., \& Cakilcioglu, U. (2013). Traditional uses of some medicinal plants in Malatya (Turkey). Journal of Ethnopharmacology, 146(1), 331-346. https:/ / doi.org/10.1016/j.jep.2012.12.054

Thaipong, K., Boonprako, U., Crosby, K., Cisneros-Zevallos, L., \& Byrne, D.H. (2006). Comparison of ABTS, DDPH, FRAP, and ORAC assays for estimating antioxidant activity from guava fruit exracts. Journal Food Composition and Analysis, 19(6-7), 669-675. https://doi.org/10.1016/j.jfca.2006.01.003

Tiberi, R., Niccoli, A., Curini, M., Epifano, F., Marcotullio, M.C., \& Rosati, O. (1999) The role of the monoterpene composition in Pinus spp. needles, in host selection by the pine processionary caterpillar, Thaumetopoea pityocampa. Phytoparasitica, 27(4), 263-272. https://doi.org/10.1007/BF02981482

Tillah, M., Batubara, I., \& Sari, R.K. (2017). Antimicrobial and antioxidant activities of resins and essential oil from pine (Pinus merkusii, Pinuso ocarpa, Pinus insularis) and agathis (Agathis loranthifolia). Biosaintifika, 9(1), 134-139. https:// doi.org/10.15294/biosaintifika.v9i1.8371

Ulukanlı, Z., Karabörklü, S., Bozok, F., Ates, B., Erdogan, S., Cenet, M., \& Karaaslan, M.G. (2014). Chemical composition, antimicrobial, insecticidal, phytotoxic and antioxidant activities of Mediterranean Pinus brutia and Pinus pinea resin essential oils. Chinese Journal Natural Medicines, 12(12), 901-910. https://doi.org/10.1016/S18755364(14)60133-3

Ustun, O., Senol, F.S., Kurkcuoglu, M., Orhan, I.E., Kartal, M., \& Baser K.H.C. (2012). Investigation on chemical composition, anticholinesterase and antioxidant activities of extracts and essential oils of Turkish Pinus species and pycnogenol. Industrial Crops and Products, 38, 115-123. https://doi.org/10.1016/j.indcrop.2012.01.016

Vankatesan, T., Choi, Y.W., \& Kim, Y.K. (2019). Impact of different extraction solvents on phenolic content and antioxidant potential of Pinus densiflora bark extract. BioMed Research International, 2019(4), 1-14. https://doi.org/10.1155/2019/3520675

Xie, Q., Liu, Z., \& Li, Z. (2015). Chemical composition and antioxidant activity of essential oil of six Pinus taxa native to China. Molecules, 20(5), 9380-9392. https:// doi.org/10.3390/molecules20059380

Yu, E.J., Kim, T.H., Kim, K.H., \& Lee, H.J. (2004). Aroma-active compounds of Pinus densiflora (red pine) needles. Flavour and Fragrange Journal, 19(6), 532-537. https://doi.org/10.1002/ffj.1337 